\title{
The application of STAD-Cooperative Learning Model: Efforts to increase motivation and Learning Outcomes of students in Class 5 SD N 07 Ledok Salatiga in Mathematics subjecth in Folding Symmetry and Rotating Symmetry topics
}

\author{
Munawar HM \\ Sekolah Dasar Negeri Ledok 07 \\ hm.munawar@gmail.com
}

\begin{abstract}
This study aims to improve the motivation and mathematical achievement of a two-dimensional figure about folding symmetry and rotary symmetry for fifth-grade students of SD Negeri Ledok 07 Salatiga in the even semester of 2018/2019. This research was conducted in the fifth grade of SD Negeri Ledok 07 Salatiga for one semester. Subjects in the study were all fifth-grade students as many as 23 students, consisting of 12 women and 11 men. This study used two cycles of action. In each cycle, it was carried out in 4 stages, namely planning, acting, observing, and reflecting. The data collection was through documentation, observation, and test results. Whereas, the research instruments were in the form of a list of values, observation sheets, and written questions. Data were obtained from observers, consisting of teachers as collaborators and the lesson grid. Data analysis used comparative descriptive followed by reflection. In the initial conditions, it turned out that learning outcomes were still low, as evidenced by students who scored 70 or more were still seven students $(34.8 \%)$. In the first cycle, students who scored 70 or more were 15 students $(65.2 \%)$. In cycle II, students who scored 70 or more increased to 21 students (91.3). Then, it can be concluded that the Student Team Achievement Division model can improve motivation and learning outcomes for mathematics in the fifth grade at SD Negeri Ledok 07 Salatiga in the second semester of 2018/2019.
\end{abstract}


Keywords: Learning motivation, Mathematics learning achievement, STAD type cooperative approach

\section{INTRODUCTION}

Learning in Elementary Schools is carried out by the teacher as a manager, so it is necessary to understand how students carry out learning activities. In this process, the teacher acts as an appropriate mediator for the learning process of students. The teacher's function as a mediator is expected to be able to motivate students in academic matters at school (Suduc, Bizoi, \& Gorghiu, 2015). From the observations, it was found that the learning outcomes of 5 th-grade students in semester 2 of SD Negeri Ledok 07 Salatiga 2018/2019 were not significant. It is evidenced by the value of learning outcomes that only seven students who scored 70 and 15 others scored below 70 . It proves that $65 \%$ of students have not reached completion. Conventional methods used by teachers should need to be evaluated with other methods and or modifications to support the achievement of student learning outcomes.

They were not using the right learning media, for example, the use of the STAD cooperative learning model to explain the material of folding symmetry and rotary symmetry that is shorter, faster, and more precise. Students were also "forced" to follow the speed of average thinking class, so students who had below-average/slow thinking ability would feel left behind, as well as students who had above average thinking ability felt not challenged. Students were not happy about mathematics, teachers were 


\section{Mudarrisa: Jurnal Kajian Pendidikan Islam, Vol. 11, No. 2, 2019}

not creative in teaching and learning activities, and they have not yet applied the Cooperative Student Team Achievement Division (STAD) model in mathematics learning. Based on field facts, less than $50 \%$ of students did not pay attention to the teacher's explanation by showing no interest in mathematics, suspected it is caused by, among others, the teacher did not have variations in the use of learning models. The author carried out Classroom Action Research (CAR) in the hope of increasing mathematics learning outcomes for the fifth-grade students of SD Negeri Ledok 07 in semester 2 of 2018/2019 on the average value of 70 and above, and all students achieve the completion in learning mathematics.

STAD-based research is very effective to be used in mathematics learning in elementary schools. The use of the STAD method can support students to be creative in implementing learning and in groups to help one another in completing lesson assignments (Bhoke, 2016: 104). In addition, the STAD method and Team Game Tournament (TGT) combined can improve elementary students' understanding in learning mathematics (Menanti \& Rahman, 2015: 38-39).

Increased learning motivation of students in grade 5 at SDN Ledok 07 can appear with the teacher applying the STAD cooperative learning model, then the STAD cooperative learning model can be used as an approach that can be applied in learning. In addition, the use of the STAD method can maximize student learning outcomes, especially mathematics, foster student learning motivation in mathematics, eliminate the fear of thinking about mathematics, train students' skills in expressing 
opinions, prove the truth of the formula by using props, and provide benefits for educators. The implementation of CAR in this study can help teachers in the process of varying learning approaches that can improve teaching and learning activities, reduce errors in learning, and increase the ability of students, especially in completing the measurement of the twodimensional figure (Astriyani, et al., 2018: 808).

The behavior of students in learning, interest in learning, attention in learning, concentration in learning, perseverance in learning are the reflection of learning motivation (Ardhana et al., 2014: 33), according to Kusnadi (2002: 330), they are efforts to bring the enthusiasm of others. This opinion can be concluded that learning motivation is a change in behavior of students, characterized by the emergence of interest, attention, concentration in learning to achieve the expected goals in learning.

Lie (2014) mentioned about learning strategies, namely competition, individual, and cooperative. Learning competition teaches students to compete with their peers. Generally, learning objectives are only achieved by a few students. Most of the students are categorized as average, and some others are in the category of failure.

STAD cooperative learning is a learning system in which there are interrelated elements. The elements are (1) positive interdependence, (2) face to face interaction, (3) individual accountability, and (4) skills for interpersonal relationships (Abdurrahman and Bintoro in Nurhadi and Gerard Senduk, 2003: 60). Cooperative learning is essential to be developed. The results showed a variety of advantages in STAD 


\section{Mudarrisa: Jurnal Kajian Pendidikan Islam, Vol. 11, No. 2, 2019}

cooperative learning. The advantages of cooperative learning according to Nurhadi (2003: 63) include: (1) Developing real joy of learning, (2) Facilitating students to make social adjustments, (3) Enabling students to learn from each other about attitudes, skills, information, social behavior, and views, (4) Eliminating selfishness, and (5) Increasing mutual trust in fellow human beings.

Slavin Nur (2005: 35) stated about three concepts, which are the main ideas for the student learning model. The three main ideas are team appreciation, individual responsibility, and equal opportunity to succeed. According to Sutopo (2006: 7), there are five main components in STAD type cooperative learning. They are class presentations, teamwork, quizzes, individual improvement scores, and team awards.

According to Andayani (2007: 23), steps in STAD learning include material preparation, material presentation, group activities, and evaluation. Meanwhile, according to the Widyaiswara Team of Central Java LPMP (2008), there are several phases or steps of the STAD type of cooperative learning. These steps are: 1) teacher presentations in front of the class, 2) teachers form groups, 3) work in groups, 4) scaffolding, 5) validation, 6) quizzes, 7) group rewards, and 8) evaluations. Most teachers are reluctant to apply it for several reasons. According to Kagan and Slavin in Larasati (2005: 37), there are several problems in implementing cooperative learning strategies. These problems are crowded, failing to get to know each other, wrong behavior, and ineffective use of time. 
STAD Cooperative Learning type has several advantages (Slavin, 1997: 17), including (1) Students work together in achieving goals by upholding group norms, (2) Students actively help and motivate enthusiasm to succeed together, (3) Being active as peer tutors to further enhance group success, (4) Interaction between students as they increase their ability to express ideas. According to Slavin (2008: 188), the steps that must be taken in STAD learning are: (1) Presentation of material by the teacher, (2) Students join in groups of 4-5 people, (3) The teacher gives the task to the group to do the exercise/discuss an advanced topic together, (4) Test/quiz or cross-question between groups, (5) Strengthening from the teacher.

According to Soewarso in Larasati (2005: 38), weaknesses that might occur are: (1) There is dependency, so students who are slow thinking cannot practice independent learning, (2) Requires a long time so that the target of curriculum achievement cannot be met, (3) Not being able to apply the subject matter quickly, and (4) Assessing individuals and groups and giving gifts makes it difficult for teachers to implement them. These weaknesses have caused many factors to affect student learning outcomes.

Achievement of learning outcomes reflects the extent to which students have been able to achieve the goals set in each subject. Numbers from 0 to 10 can express the description of student achievement (Arikunto, 1998). Meanwhile, Arifin (1999) said that learning achievement is the achievement of an effort, ability, and attitude of a person in 


\section{Mudarrisa: Jurnal Kajian Pendidikan Islam, Vol. 11, No. 2, 2019}

completing a matter, in the field of education. Measurement of learning achievement (Scott, 2004: 42) is based on a variety of different forms. The most common measurement is taken from test scores, either oral, written or assignment. In this study, the learning outcomes of students in the cognitive domain of mathematics learning were compared between initial and final test scores, using the cooperative learning approach of the STAD model.

The STAD method was regarded as necessary as a manifestation of cooperative learning, which is better than individual learning (Tosto et al., 2016: 261). Individual learning models will teach students to learn alone to achieve learning goals, and there is almost no interaction with peers. It will teach students to get accustomed to the view that the achievement of learning goals has nothing to do with other students. Thus, the lives of students are focused on the interests of their achievements and ignoring other friends.

The cooperative learning model is a learning model to achieve academic standards for students who are grouped in several small groups and guided by educators consisting of various scientific disciplines working together to deliver learning material to students. There is an element of positive interdependence between educators, shared responsibility in helping one another among educators with efforts to always improve their abilities. Teachers feel they have the same goals in education for all students, and the learning process involves all components to contribute 


\section{Mudarrisa: Jurnal Kajian Pendidikan Islam, Vol. 11, No. 2, 2019}

to all students, and all are responsible for students in unlimited time (Priyatni, 2016: 292).

According to Johnson \& Johnson (2014), the cooperative learning approach is one of the teaching approaches applied to small teams, consisting of students with different levels of ability. Group achievement in achieving learning outcomes and completing tasks together in groups is the primary goal. Cooperative teaching and learning approaches can be used for each subject at each grade level without a specific curriculum, and it can develop and use critical thinking skills in the implementation of peer training, interdependent positively to develop social skills for the common good without distinguishing gender, race, culture, and language. Small groups are not temporary in collaboration (working only in class), but cooperation is ongoing so that individual competition is unfairly changed in cooperative structures.

The cooperative learning approach is to enhance cooperation in groups, thereby changing the way of individualistic learning that is competitive in the form of cooperative learning (Yamtim \& Wongwanich, 2014: 922). Achievement research on cooperative learning approaches can be classified into three categories, namely: higher student achievement and greater productivity, mutual attention to mutual support and forms of responsible relationships, better mental health, social competence, respect for others (Johnson \& Johnson, 2014: 214).

Improving the quality of schools is not determined by the building, curriculum, schedule, and learning tools, but the school focuses on the 


\section{Mudarrisa: Jurnal Kajian Pendidikan Islam, Vol. 11, No. 2, 2019}

interaction between humans that are regulated in the school curriculum. The collaboration will determine the effectiveness of these schools. Collaboration between students is fundamental in learning. Cooperative learning begins by forming group work in the classroom. The expected outputs are students with improved learning outcomes, better relationships, and positive psychiatric conditions. Prerequisites and foundation of cooperative learning for instructional innovation include an integrated curriculum, a variety of commonly known languages, critical thinking, active writing and reading, and an ability to interpret authentically. Cooperative learning to improve student productivity, morale, and teacher professional appreciation needs to be formed in a team with the aim of (1) Improving sustainable skills, and (2) Teaching staff meetings. It is to present the mindset of the administrators, how school management should be, and joint agreement in implementing a model in learning activities (Johnson \& Johnson, 2014: 312). They suggest that teaching staff meetings are carried out in an orderly and regular manner conducted by schools both in the form of formal and informal meetings as well as training and development. Cooperative learning has three positive things, namely: achieving good learning outcomes and higher learning productivity; a willingness to share, support each other, and be responsible; increased psychological health, sociological, and self-confidence.

In addition, the STAD method can encourage students to be skilled in utilizing learning media (Ningsih, 2015: 1920). Therefore, the 
research focuses on the use of the STAD method to increase the learning motivation of 5th-grade students at SD Negeri Ledok 07 Salatiga. The novelty of this research is about the application of the STAD method in motivating elementary school students in Mathematics.

\section{METHODS}

Research Methods

This research was conducted by the experimental method and class action (CAR). This class action research was conducted in the 2018/2019 academic year in the even semester for four months. Data collection used techniques: (1) test techniques, to determine the ability before action was taken, when action taking, and after the action was completed (end of cycle), (2) questionnaire distribution, in order to know cooperation in the group, (3) Observation: for data collection relating to collaboration with groups, (4) Documentation: in order to collect data in the condition prior to conducting action research.

The place of research was applied to grade 5 of SDN Ledok 07. The target in this study were all grade 5 students in the even semester of the 2018/2019 academic year on folding symmetry subjects at SD Negeri Ledok 07 totaling 23, consisting of 7 men and 16 women. Additional data derived from the scores obtained by students before the CAR was carried out to determine the initial ability before the research was held. One month after that was used to collect the necessary data and took action on the target class. In the next two months, the authors took advantage of the analysis of the data obtained, followed by discussion. In 


\section{Mudarrisa: Jurnal Kajian Pendidikan Islam, Vol. 11, No. 2, 2019}

the fourth or last month, the researchers took advantage of making reports on the results of action research - the achievement of learning outcomes obtained through documentary studies. The measuring instrument used as an evaluation in the form of a test was prepared by the researcher, fifthgrade teachers, and guides. The final condition was seen in the learning outcomes of the first cycle and the second cycle. The assessment material in the form of questions must be tested for validity by being tested in a class that was not used for research. The results of data of cooperation and cooperative learning motivation of the STAD model from interview techniques, observation techniques, and questionnaires were analyzed by using descriptive qualitative analysis. Then, the learning achievement data obtained from tests and documents were analyzed with descriptive comparative.

The flow of Classroom Action Research Method

Classroom action research was conducted in two Cycles, namely Cycle I and II with the following description:

\section{Cycle I}

The purpose of this cycle was the formation of discussion groups and solving problems faced by students in the learning process. The formation of learning discussion groups was expected that teaching and learning activities and achievement of learning outcomes would increase: (1) The preparation period; researcher, teachers, and school principals prepared material in the form of preparing lesson plans, learning group formation techniques, and the formation of student groups between 5 to 6. (2) 
Action implementation; it must be in accordance with lesson plans that had been prepared. It was ensured that all students learned actively in groups. During the learning process, observations were held by the researcher, Principal, and guides. (3) The next step was to reflect on the evaluation of learning implementation in cycle I based on tests of learning achievement results, observation, interviews, and questionnaires, in order to see the level of progress in conducting research, obstacles encountered, and other supporting factors.

Cycle II

Based on the results of cycle 1 reflection, then cycle 2 was done by taking into account the constraints faced by the supporting factors in the implementation of Cycle 1. The implementation of the second cycle was the same as the first cycle, but the group members were reduced from 5-6 to 3-4 students per group.

\section{DISCUSSION}

Before the research began, an analysis was carried out to map the learning outcomes of students, so that the following data were obtained. 


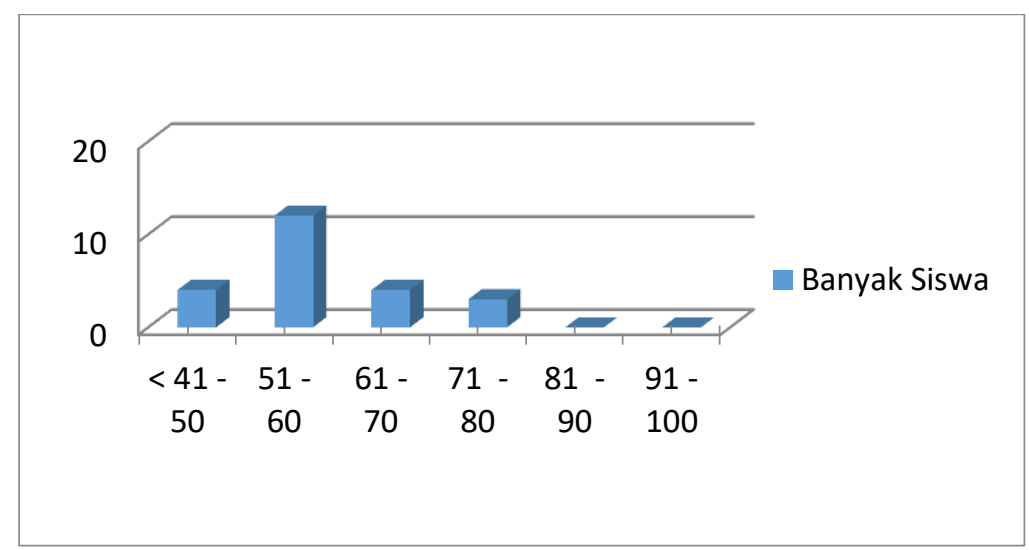

Figure 1. Diagram of learning outcomes for grade 5 students of SD Negeri Ledok 07 Salatiga prior to the implementation of the study Diagram in Figure 1 showed the results of the analysis that a total of 4 students out of a total of 23 students received a score of $41-50$, a total of 12 learners received a score of $51-60$, a total of 4 learners received a score of $61-70$, a total of 3 learners received a score of $71-80$, and there were no students who scored $81-100$. It indicated that there was one notachieved in the acquisition of a high-value score scale. Furthermore, the cycle activities began with the first cycle, followed by the next cycle.

\section{Cycle I}

Cycle I was carried out with the acquisition of a total of 23 students getting a score of learning outcomes of $40-50,2$ students obtained a score of learning outcomes $51-60$, a total of 6 students obtained a score of learning outcomes of $61-70$, a total of 10 students obtained a score of learning outcomes $71-80,5$ students received a score of learning outcomes $81-90$, and no students who obtained a score of learning 
outcomes 91-10. The results of the 1st cycle Mathematics assessment are in the diagram in Figure 2.

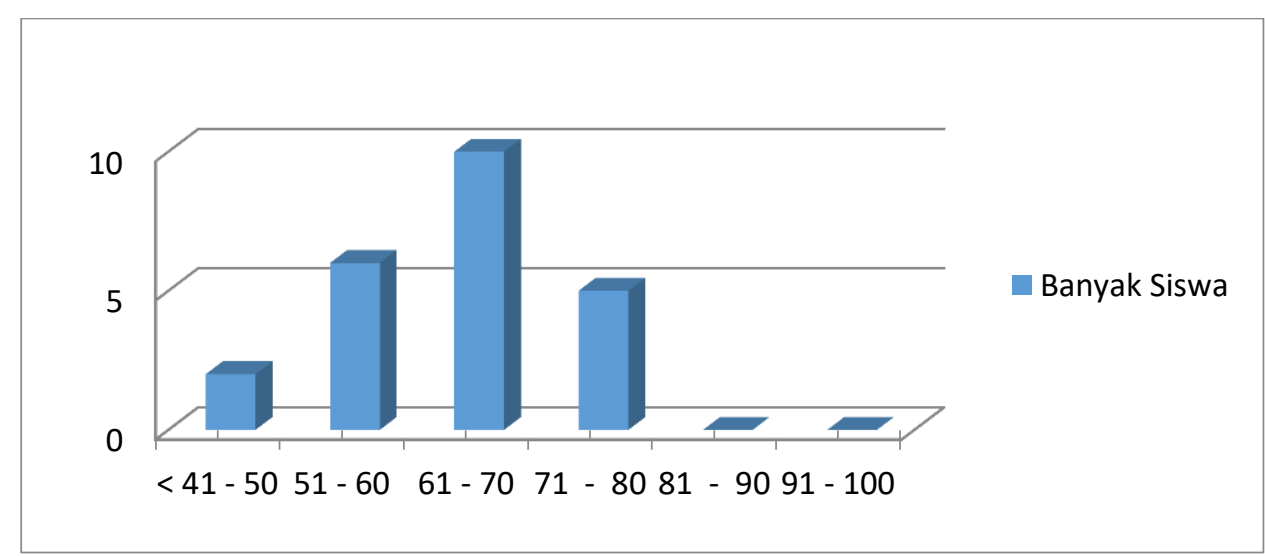

Figure 2. Score learning outcomes using the STAD method in Cycle 1 Diagram Figure 2 also shows that out of 23 students, the smallest number was 50 , and the highest number was 80 . Students who got the number 70 or more were 15 students, smaller than 70 were eight students, and the mean value was 66.82 . It can be concluded that learning in the first cycle has improved, yet, the attainment of completeness was still $65.21 \%$.

The use of the STAD method and motivating in the form of encouragement, enthusiasm, ideas, and togetherness to students can improve the learning outcomes of students () (Hobri et al., 2018: 485; Kiemer et al., 2015: 95-96; Triyuni, 2016: 95). It was proven as observed in Tabel 1.

Table 1. Observation result of students' attitudes in the Cycle I learning No. Observation Score category

Average in Low Enough High class

$\begin{array}{lllll}\text { 1. Support } & 5 & 15 & 6 & \text { enough }\end{array}$




\begin{tabular}{|c|c|c|c|c|c|}
\hline \multicolumn{6}{|c|}{ (encouragement) } \\
\hline 2. & Enthusiasm & 3 & 16 & 5 & enough \\
\hline 3. & Ideas & 2 & 13 & 8 & enough \\
\hline 4. & Togetherness & 3 & 13 & 7 & enough \\
\hline
\end{tabular}

Students dare to answer questions and dare to ask the teacher if they have difficulty, more confident, as it can be seen in the above table. The motivation given to students could provide the effect of encouragement, conceptual togetherness, and implementation by placing students in the right situation (Hobri, Dafik, 2018; Katharina Kiemer, Alexander Groschner, Ann athrin Pehmer, 2015).

Thus, the learning outcomes of students in Cycle I experienced significant progress. It was indicated by the results of an average learning value of 65.21. The implementation of the 1st cycle learning process had not been carried out optimally by the teacher, both in the use of learning tools and teaching methods, so that student learning outcomes were still lacking. The cooperative learning model of the STAD model had not been able to motivate students to learn, and the task had not been done well. Overall, of the 23 students, 15 students met the minimal completeness criteria (KKM), and eight other students had not yet reached the KKM, 65.21\%. Thus, it was necessary to continue Cycle II.

\section{Cycle II}

From the results of the second cycle of research, one student obtained a score of learning outcomes 41-50, two students obtained a score of learning outcomes $51-60$, seven students obtained a score of learning 
outcomes $61-70$, eight students obtained a score of learning outcomes $71-80$, six students received a score of learning outcomes $81-90$, and there were no students who obtained a score of learning outcomes 91-100. Student learning outcomes scores in Mathematics in Cycle II are shown in Figure 3.

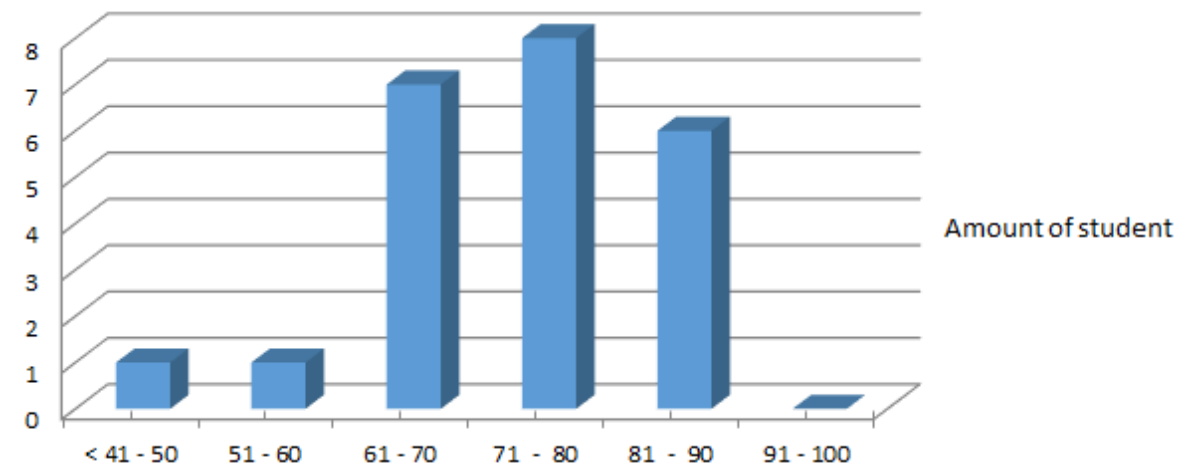

Figure 3. Diagram of the results of the Cycle II learning outcomes Observations in Cycle II showed that teachers delivered Mathematics lessons using the STAD method appropriately and provided encouragement to students to be more attentive and active. As in Table 1.

Table 1. Observation results of student's attitude in Cycle II learning

\begin{tabular}{clcccc}
\hline No. & Observation & \multicolumn{3}{c}{ Score category } & Average in \\
\cline { 2 - 4 } & & Low & Enough & High & Class \\
\hline 1. & $\begin{array}{l}\text { Support } \\
\text { (encourageme }\end{array}$ & 4 & 7 & 12 & high \\
& nt) & 6 & 7 & 10 & high \\
\hline 2. & Enthusiasm & 4 & 7 & 12 & high \\
\hline 3. & Ideas & 3 & 9 & 11 & high \\
\hline 4. & Togetherness & & & & \\
\hline
\end{tabular}


The STAD cooperative learning model implemented in Cycle II gave better results than in Cycle I. In addition, props were prepared for each group of students. Performance results showed more improvement compared to Cycle I. It could be seen from the learning that can be achieved as expected, namely achieving completeness. In this study, completeness reached $91.30 \%$, and there were 21 students out of 23 students who reached completeness. The mean value was 77.39. Completeness of learning from cycle to cycle can be seen in the following table.

Teacher motivation and encouragement will support students' learning performance. It is supported by the statement that the encouragement and motivation of teachers can foster positive attitudes and logic in learning mathematics, as well as interpersonal relationships in groups (Hobri et al., 2018: 487).

\section{Cycle I and Cycle II}

The completeness limit was a score of 70 or more than a score of 70 . Before using the STAD method, a total of 7 students or around $34.78 \%$ had met the KKM. Learning activities in Cycle I increased to 15 students or $65.21 \%$. After Cycle II, 21 students or around $91.30 \%$ reached the KKM. The STAD method after Cycle II showed success. It can be seen in the diagram below. 


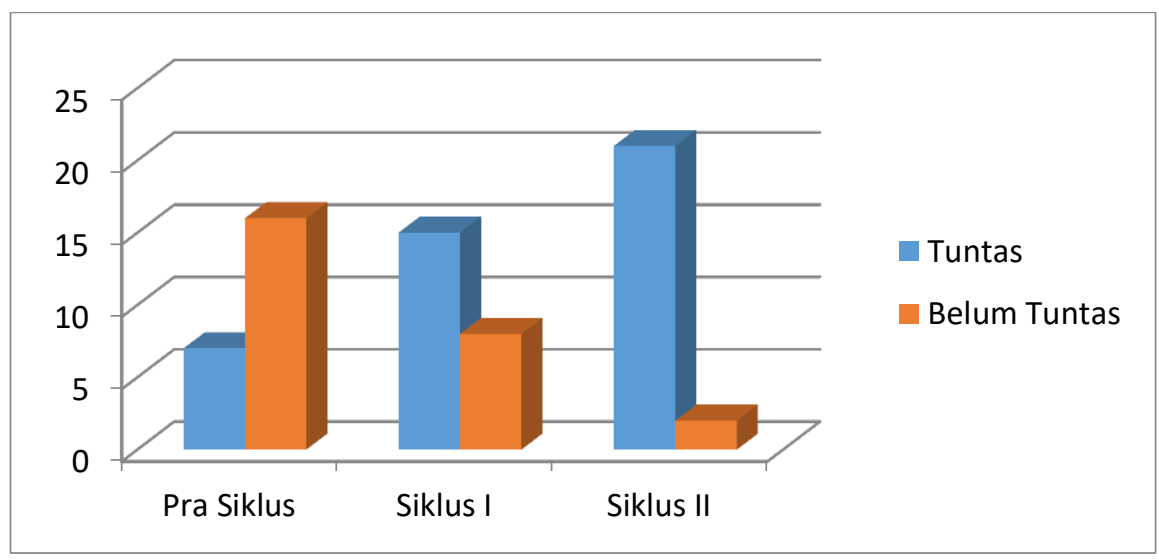

Figure 4. Diagram of learning outcome scores before and after research in each cycle (blue: complete, brown: incomplete)

KKM scores obtained in the pre-cycle, Cycle I, and Cycle II describe significant changes in student learning outcomes, as in Table 2.

Table 2. List of Minimum Criteria for Completeness (KKM) in Mathematics for students of SD N Ledok 07 Salatiga before and after the use of the STAD method

\begin{tabular}{|c|c|c|c|c|c|c|c|}
\hline \multirow[t]{2}{*}{ No. } & \multirow{2}{*}{$\begin{array}{c}\text { Minimum } \\
\text { Completeness } \\
\text { Criteria } \\
(\mathrm{KKM}) \\
\text { Achievement }\end{array}$} & \multicolumn{2}{|c|}{$\begin{array}{l}\text { Before using the } \\
\text { STAD method }\end{array}$} & \multicolumn{2}{|c|}{ Cycle I } & \multicolumn{2}{|c|}{ Cycle II } \\
\hline & & $\begin{array}{c}\text { Number } \\
\text { of } \\
\text { students }\end{array}$ & $\begin{array}{c}\text { Percen- } \\
\text { tage } \\
(\%)\end{array}$ & $\begin{array}{l}\text { Number } \\
\text { of } \\
\text { students }\end{array}$ & $\begin{array}{l}\text { Percen- } \\
\text { tage } \\
(\%)\end{array}$ & $\begin{array}{c}\text { Number } \\
\text { of } \\
\text { students }\end{array}$ & $\begin{array}{l}\text { Percen- } \\
\text { tage } \\
(\%)\end{array}$ \\
\hline 1. & Achieved & 7 & 34.8 & 15 & 65.2 & 21 & 91.3 \\
\hline 2. & Not achieved & 16 & 65.2 & 8 & 24.8 & 2 & 8.7 \\
\hline
\end{tabular}

Table 3 showed that the learning achievement of students in Cycle I and Cycle II indicated that in the learning process, a professional and competent teacher is needed, which influences failure and success in the learning process. Based on theories relating to learning, the intelligence of educators in managing teaching and learning activities includes using strategies, choosing methods, and learning media (Gurses et al., 2015: 
45-47). The process of teaching and learning managed to run well, as evidenced by the completeness, which reached $91.3 \%$ or a total of 21 students out of a total of 23 students who achieved completeness with an average score of $77.39 \%$.

It shows that the STAD cooperative learning model can facilitate students to work together in small groups and help each other to learn. Cooperative learning refers to a variety of learning methods in which students work together in a small group to help each other learn the contents of the material. Cooperative learning allows students to help other students, discuss, and argue for receiving knowledge and fill gaps in understanding.

\section{CONCLUSION}

Based on the data in this study, an effective teaching and learning process in learning Mathematics subjects about folding symmetry and rotary symmetry by utilizing optimal media and teaching aids can further stimulate students' participation, as evidenced by the author's experience to have a research in the fifth grade of Sekolah Dasar Negeri Ledok 07 Salatiga in the even semester. It is indicated by the mathematics learning achievement based on the completeness of the results before the improvement (Pre-cycle) with a percentage of $34.78 \%$, Cycle I with a percentage of $65.21 \%$, and Cycle II as much as $91.30 \%$. From the acquisition of these values, the score of learning outcomes in pre-cycle up to Cycle II experienced a change of 56.52\%. 
Therefore, it can be suggested that the teacher should further develop creativity, meaning that the teacher should always be creative in various ways of giving lessons so that students can receive the material presented using the right method. Also, the teacher should choose the media optimally, especially the existing media that the students have known, so students are more impressed. When learning mathematics, teachers should explain in advance how it works. Thus, STAD cooperative learning models can be applied to mathematics learning.

\section{REFERENCES}

Agung Iskandar Agung. (2015). Meningkatkan Kreativitas Pembelajaran Bagi Guru, Jakarta: Bestari Buana Murni

Andriani Ningsih, P. (2015). Pengaruh Penggunaan Media Batang

Cuisenaire terhadap Hasil Belajar Siswa pada Materi Penjumlahan

Dan Pengurangan Bilangan Di Sekolah Dasar. Jurnal Penelitian Pendidikan Guru Sekolah Dasar, 03(02), 1912-1921.

Astriyani, Triyono, I. H. (2018). Hubungan Motivasi Belajar dan Tindakan

Guru dengan Prestasi Belajar Siswa dengan Latar Belakang Broken Home Kelas V Sekolah Dasar. Jurnal Pendidikan: Teori, Penelitian, Dan Pengembangan, 3(6), 806-809.

Gurses, A., Demiray, S., \& Do, C. (2015). A Design Practice For Interactive- Direct Teaching Based On Constructivist Learning (IDTBCL): Dissolution And Solutions. Procedia-Social and Behavioral Sciences, 191, $44-49$. 
Hobri, Dafik, A. H. (2018). The Implementation of Learning Together in Improving Students '. International Journal of Instruction, 11(2), $483-496$.

Hotmaria Menanti, A. A. R. (2015). Perbandingan Kemampuan Pemahaman Konsep Matematika Siswa Menggunakan Model Pembelajaran Kooperatif tipe STAD dengan TGT di SD Islam Khalifah Annizam. Jurnal Bina Gogik, 2(1), 38-48.

Katharina Kiemer, Alexander Groschner, Ann athrin Pehmer, T. S. (2015). Effects of a classroom discourse intervention on teachers ' practice and students' motivation to learn mathematics and science. Learning and Instruction, 35, 94-103. https://doi.org/10.1016/j.learninstruc.2014.10.003

Suduc, A., Bizoi, M., \& Gorghiu, G. (2015). Inquiry Based Science Learning in Primary Education. Procedia - Social and Behavioral Sciences, 205(May), 474 479. https://doi.org/10.1016/j.sbspro.2015.09.044

Tosto, M. G., Asbury, K., Mazzocco, M. M. M., Petrill, S. A., \& Kovas, Y. (2016). From classroom environment to mathematics achievement: The mediating role of self-perceived ability and subject interest. Learning and Individual Differences.

Triyuni. (2016). The Influence of Science Learning set using Scientific Approach and Problem Solving Model on Learning Outcomes of Junior High School Students in The Subject of Heat and Temperature. Jurnal Pendidikan IPA Indonesia, 5(2), 177-185.

Wilibaldus Bhoke. (2016). Pengaruh Model Pembelajaran Kooperatif Tipe 
Mudarrisa: Jurnal Kajian Pendidikan Islam, Vol. 11, No. 2, 2019

Student Teams Achievement Division (STAD) dan Motivasi Belajar Terhadap Hasil Belajar Matematika Siswa Kelas V SD Gugus 2 Kecamatan Bajawa Kabupaten Ngada-Flores. Jurnal Ilmiah Pendidikan Citra Bakti, 3(1), 102-112.

Yamtim, V., \& Wongwanich, S. (2014). A Study of Classroom Assessment Literacy of Primary School Teachers. Procedia-Social and Behavioral Sciences, 116, 2998-3004. 